\title{
The Value of International Regime and Global Environmental Crisis
}

\section{Budi Winarno}

International Relations Department, Faculty of Social and Political ScienceGadjah Mada UniversityBulak Sumur, Yogyakarta 55281

Email:winarno@ugm.ac.id

Submitted: 03 February 2017, Accepted: 05 April 2017

\begin{abstract}
Abstrak
Globalisasi telah memicu kompetisi ekonomi yang menyebabkan eksploitasi sumber daya alam secara berlebihan. Eksploitasi ini mengakibatkan krisis lingkungan global yang membutuhkan perhatian dan tindakan penanggulangan dari komunitas internasional secepatnya. Meningkatnya kesadaran masyarakat global terhadap isu ini ditandai dengan munculnya berbagai bentuk kerjasama di tingkat regional maupun internasional. Beberapa kerjasama berbentuk rezim internasional bertujuan untuk mengusulkan keterlibatan seluruh aktor dalam menghadapi krisis lingkungan tersebut. Akan tetapi, pandangan neoliberalisme terhadap perkembangan ini melihat adanya kompetisi ekonomi yang tidak terelakkan sehingga rezim tersebut menjadi tidak efektif. Ketidakpatuhan negara anggotanya, terutama negara-negara industri berskala besar, membuat semakin diperlukannya solusi alternatif.

Kata kunci: krisis lingkungan, perubahan iklim, ancaman global, keamanan manusia, pemanasan global, rezim internasional, organisasi regional.
\end{abstract}

\begin{abstract}
Globalization has brought the world toward economic competition that causes excessive exploitation of resources. This exploitation led to a global environmental crisis that needs to be addressed by the international community soon. The increasing awareness of the world community on this issue is marked by the emergence of various kinds of cooperation at the regional and international levels. The existence of an international regime which is aimed at addressing the issue of environmental crises will be able to achieve its objectives if all the actors involved obey the mutually agreed terms. However, as neoliberalism in development sees that aggressive economic competition is inevitable, the international regime becomes ineffective in performing its role due to non-compliance committed by its participants, especially the industrialized countries which contributed the greatest damage to the global environmental crisis so another alternative solution is needed. Keywords: overexploitation of natural resources, environmental crisis, global warming, climate change, global threat, human security, international regime, regional organization.
\end{abstract}

\section{INTRODUCTION}

Global warming is a low political issue which in recent years has contributed significantly to the dynamics of global high politics. Global warming is regarded as one of the consequences of globalization. In the era of globalization, neoliberal principle encourages the emergence of market power where the greatest power in the economic field is held by the owners of capital and the benchmark for the advancement of a state seen from the progress of the industry of a country. To pursue economic growth, a state is required to increase production and consumption to improve their industry. This encourages the consumption of fossil-based energy becomes very large and unmanageable.
Development based on the principles of neoliberal causes the emergence of the phenomenon of over-exploitation of natural resources, leading to a global warming or environmental crisis. Environmental degradation is a cross-border issue as its impact is felt by all human beings on earth. Air pollution, global warming, climate change, animal extinction, water pollution, ozone depletion, and environment degradation become global problems that must be resolved through a global cooperation.

Institutionalist perspective which emphasizes the need for global institutions and a strong norm used to further examine these issues. Institutionalists believe that the in- 
stitutions need to internalize the principles of sustainable development, including in the decision-making process of the state bureaucracy, companies, and international organizations. The purpose of this approach is to ensure that global economic policies can improve the environment and living standards. Therefore, the international regime needs to be strengthened to solve the environmental crisis. This article is written to explore further, how the international regime that theoretically can drive the resolution of environmental crisis issues fails to apply its values to international relation practices regarding this issue by elaborating the concept of globalization, industrialization and economic development, and neoliberalism in development.

\section{THEORETICAL FRAMEWORK}

\section{GLOBALIZATION}

According to the British sociologist Anthony Giddens (1990) globalization is global expansion of Western modernity (Giddens, 1990:64). This assumption is not only stated by Giddens, but also by Holland Professor, a sociologist, Jan Nederveen Pieterse (1995). Pieterse admits that many views about globalization interpret it as the ultimate consequence of the globalization of modernity. He also added that the phenomenon is most often interpreted as the world becomes more uniform and standards through technology, commercial, and cultural synchronization from the West (Pieterse, 1995).

Pieterse's statement above has two implications centers, first, they imply that globalization is seen as something that is born from modernity, mode of social life, values, and organizations from the West, because the globalization certainly stand up to 'color' the West with all values and development process. As a result, globalization can be seen as a stage to enhance the cultural hegemony of certain central along the trajectory of modernity. ${ }^{1}$ For this reason, from the 70s onwards, globalization has been associated with standardization-homogenization process of economic institutions-of political, symbolic practices, consumer habits and lifestyles around the world. Modernity is 'inherently globalizing' and borrow a phrase from Gidden, 'inherently westernising' (Giddens, 1990:63). Another perspective which can be used to understand the complexity of this phenomenon is the view of Jonathan
Friedman, and is also inspired by the culture of sociology, thinks globalization is a recognition of what is understood as an increase in interconnected worldwide, stacking and movement of people, images and commodities (Friedman, 1994:69). More details he said that culture with regard to the implications of global communication in relation to the generation of cultural products ranging from standardization to postcolonial multiplicity. And in economics, globalization refers to the internationalization of the economy and the spread of capitalist market relations (Friedman, 1994:69). But Friedman not only confirms that many of the categories of globalization is the product of ideological discourse of 'modernity', but also recognizes that this discourse direct the connection to the modern era.

\section{INDUSTRIALIZATION AND ECONOMIC DEVELOPMENT}

It was explained earlier that globalization is understood as a phenomenon of the evolution of the world into the modern era. Globalization encourages the countries in the world to compete to revolutionize their industry. Why? Because in the process of economic globalization, there are a few of the many forces that have created a global market (Steiner and Steiner, 1994: 389-390). Over the past quarter-century, the world's gross national product is growing rapidly, especially in the developed countries in the world. Exports and imports expanded faster than previously described with the new demand for goods from industrialized countries. Due to a large demand for goods, industrial countries felt the need to revolutionize their industry and cut production costs and improve product quality. The era of economic globalization accompanied by rapid development of technology, have very tight competition and the rapid changes in the business environment. Products of manufacturing in the country is now directly compete with foreign products, and the business world must also accept the fact that the rapid development of technology has resulted in rapid obsolescence of production facilities, the short shelf-life products, as well as with shrinking profit margins, in carrying out the process of industrial development, the situation is a reality that must be faced and should be the determining consideration in any policy to be issued, and is a new paradigm that must be faced by any country in implementing the 
industrialization process of the country. On the basis of this conceptual world in industrial development policy should be able to answer the challenges of globalization of the world economy and able to anticipate the development of rapid environmental change (Brandon Levy, 2012, p. 137).

International economic competition is a new perspective for all countries, so that the focus of industrial development strategy for the future is to build the competitiveness of the industrial sector which is sustainable in the domestic and international markets. To build sustainable competitiveness, efforts to use the whole potential of the nation's available resources and the ability to exploit the opportunities that exist both outside and inside the country must be optimal. Therefore, the essence of sustainable competitiveness lies in how to mobilize and organize all potential productive resources, in order to meet the needs and market demand. The era of globalization and economic liberalization has brought renewal very fast and far-reaching impact on the economy, both domestically and internationally. Felt the most impact is the increasing competition in the industrial sector. To build the industrial sector in order to grow in the arena of competition such as this and at the same time making it as a driving force of the national economy in the future, the industry needs to have high competitiveness because of the strong structure, greatly increasing the added value and productivity throughout the chain value of production, and support of all productive resources are owned by the world. Increased industrial competitiveness in a sustainable form the foundation for a strong economy in the form of macro-economic stability, the business climate and a healthy investment (Brandon Levy 2012, 137).

\section{NEOLIBERALISM IN DEVELOPMENT}

The evolution of the world into an era of globalization has also become an entry point for neoliberal to instill their principles. Heightened industry competition made countries increasingly prioritize the development of their industry. The era of globalization is the era in which the progress of the industry is used as a benchmark to determine how a country has developed or been managed (Clarke Simon, 2005). Neoliberalism is also known as a mind that understands the economy which refers to the philosophy of political economy's decade-late second century, neoliberalism is actually a redefinition and extension of classical liberalism that is influenced by the theory of neoclassical economics that reduce or reject the inhibition by the government in domestic economy because it will lead to corrupt behavior. This insight focused on free markets and free trade that remove barriers to international trade and investment so that all countries can benefit and improve living standards through increased efficiency and modernization of trade and investment. Neoliberalism aims to increase market power refers to freedom. As in the case of wages, government understanding of neoliberalism no right to interfere in the determination of the worker's salary because it is a matter between the employer and the owner of capital. The main driver of market forces is the privatization of economic activities, especially in the industry's efforts owned-managed by the government.

Neoliberalism is actually a redefinition and extension of classical liberalism influenced by neoclassical economic theory that reduce or reject an inhibiting factor by the government in the domestic economy because it will lead to the creation Distortion and High Cost Economy which will then lead to corruptive behavior (Palley, 2004). This understanding focusing on free markets and free trade to knock down barriers to international trade and investment so that all countries can benefit from the rising living standards of people or people of a country and modernization through increased efficiency of trade and investment flows.

The Saxon economic liberalism believes that economic growth is achieved as a normal result of 'free competition'. Aggressive competition is a result of the belief that consider the 'free market' is a precise and efficient way to allocate natural resources are scarce people to meet human needs. Neoliberalism aims to restore confidence in the power market, with the justification that refers to freedom (Friedman M., 2002:8-9). As in the case of workers' wages, the government's understanding of neoliberalism that no right to interfere in the determination of the worker's salary or in issues of labor entirely this case is a matter between the employer owners of capital and workers. The main drivers of return of market forces is the privatization of economic activities, especially in the industrial businesses 
owned or managed by the government. But privatization is not the case in the major capitalist countries, it happens in the countries of South America and the poorer developing countries more. This privatization has defeated a long process of nationalization which is a key state-based welfare. Nationalization which inhibit the activity of entrepreneurs should be abolished. Revolution neoliberalism significant alternation of an inventory management based economy to one based on demand (Friedman M., 2002:12).

Based on the explanation of the principle of construction according to neoliberalism, economic actors are required to compete with one another to control the market. The market system tend to be only concerned with the pace of the economy, by which the effects on the environment less attention. Weak state control on economic activities is also one reason why countries such as China, neoliberals experiencing environmental problems such as high levels of pollution in the country (Lewis, 2005). State, neoliberals will give priority to industrialization to show the strength of the economy and the market. Policies which implemented neoliberal economic system triggers an increase in the income gap. Where neoliberal policies greatly facilitating free trade of goods and services, which is marked by the elimination of all forms of tariffs and import duties. In the analytical section, this perspective will then look at how state actors cannot comply with the international regime in dealing with environmental crisis issues because of the economic competition.

\section{RESULT AND ANALYSIS}

GLOBALIZATION AND CONSPIRACY OF IPE (EXPANSION MNC) AND ITS IMPACT ON THE ENVIRONMENT

Since the collapse of communism and the end of the cold war period of the early decade of the 80 s, politically practical world entered a period PaxAmericana. Namely, all States would not want to do a political adjustment of the political forces and the US military and its allies (of the G-7). ${ }^{2}$ It also brings economic consequences. The concept of globalization transformed like 'a fertilizer' for the economic growth of a nation. This sleight of hand is reinforced by Bruff's (2005) argument which says that the discourse of globalization is often propped up by economic interests (Bruff, 2005). Even many global economists in detail to say that globalization is an appropriate strategy for the benefit of multinational companies, such as lower taxes and loose regulation. The United States promoting globalization discourses to justify neoliberalism that they have the economic or political commitment. Thus globalization discourse is rooted in the efforts of a giant corporation or the US to pursue their interests and power (Martell, 2009).

Thus, the implications can be seen with the naked eye, the world has entered into a monolithic institutionalized neoliberal economic system into international agreements. ${ }^{3}$ The development of industry and globalization followed by the emergence of multi-national corporations operating in various countries to expand their markets. The fast development of MNCs is a quite significant influence for the economic development of a country and eliminate the sovereignty of the country, especially in developing countries that are in need of foreign investment to sustain development so directly MNCs can influence the formation of a policy established by the government.

But in some cases, MNCs often act arbitrarily against the host country, it is because there is a difference between the government's goal with the company's goal. The reason a country to allow entry of MNCs in addition to earn an income that will be used for the allocation of development, where Multi-national Corporations can absorb a lot of labor, thereby reducing unemployment and the most important is how the results of these investments will improve the welfare of the community. But on the other hand, the company's goal is to obtain the maximum benefit with minimum capital so that companies pay less attention to the standards that should be applied to one of the waste industry. Most companies often ignore the regulations because it requires more costs and will reduce profits. This is evidenced by the UN Report which stated that 'there was a growing gap between the efforts to reduce the impact of business and industry on nature and the worsening state of the planet' and that 'this gap is due to the fact that only a small number of companies in each industry are actively integrating social and environmental factors into business decisions. (Shah, 2002).

Large companies, especially those oriented to the natural resources sector contributed most to the environmen- 
tal degradation. In the production process, the company is highly dependent on the availability of natural resources. They continue to operate by exploiting the available raw materials, such as mining, timber and oil. In conducting the exploitation of raw materials, there is no doubt the process is very damaging to the environment and it takes a long time to restore balance to the ecosystem, for example for the manufacture of paper, the timber needs to be in the cutting of forests, and the time required to wait for the tree to grow again is not fast. Actually, the economic advantage gained by a company is not comparable to the losses in the sector were exploited in the nature.

\section{POPULATION GROWTH, ECONOMIC DEVELOPMENT, AND EX- PLOITATION OF NATURE}

The growth of the population promotes the necessity of life that affects the level of development and thus requires the exploitation of the larger resources. This is then used by MNC to gain profit. However, the exploitation of nature causes a lot of problems, especially in the natural resources that cannot be renewed. Various types of minerals, such as oil, natural gas, and coal are natural resource that will someday run out and cannot be updated again. The increasing of population means the increasing of the necessities of life. The activities of human to meet their needs often cause adverse effects on the environment. For example, to fulfill the needs of building materials and paper, then they cut woods in the forest. To fulfill the needs of agricultural land, the forests, and bogs/peatlands drained. To fulfill the needs of clothing, founded a textile factory. To speed up the transport, created various types of motor vehicles. If it's not done correctly, activities such as these examples could eventually cause environmental pollution and damage the ecosystems. For example, uncontrolled deforestation can lead to various disasters such as floods and landslides, and can eliminate the rich biodiversity in the forest. If the environmental capacity is limited, the needs of the next generation become unsecured (Brown, 1992).

All human needs that are supplied from the environment are natural resource. Natural resources are all things that can be obtained from the environment to human needs. The increasing of natural resources consumption is in addition to meet the needs of the population rise. Example: foods, clean water, clean air, and other needs. The increase of population will arise various problems, such as traffic density resulting in air pollution, a lot of agricultural land used as residential areas resulting in slum settlements, logging is used for the settlement and fulfillment, and ultimately come to be the problem of clean water. Increasing number of the population, followed by the increasing needs of the population will rise to the phenomenon commonly referred to as over-consumption. Environmental damage caused by human activity is much greater than the environmental damage caused by natural processes. Environmental damage caused by human activity occurs in various forms such as pollution, dredging, deforestation for various purposes, and etc. (Brown, 1992).

The increasing needs of human life due to population growth and increased welfare of the world are accompanied by an increasing of human needs on the one hand. Meanwhile, the traffic of modern technologies which facilitate human cultivate a limited natural resource and environmental wisdom which often develop as a control has been forgotten. Processing of natural resources and environmental management that is denied for the sake of the fulfillment of human needs are likely to continue to increase in number, variety, and quality. The rapid advancement of modern technology is not equitably followed by the development of social institutions as a control, which can damage the environmental balance. The quality of the population has become a growing problem. To be used for construction, residents need to have this level of productivity and adequate quality in terms of both physical and non-physical. Without this increase, a large population will cause problems in the future and a burden of development and natural resources. This is then also unfortunate because this experience is done simultaneously by the entire world community and cause the occurrence of tragedy of common events.

\section{TRAGEDY OF COMMONS}

In explaining the occurrence of global warming and environmental crisis, the term tragedy of commons is often associated become a key cause of the environmental crisis. It is not surprising that environmental damage is 
the responsibility of fully human, one of the causes of change and environmental degradation is a tragedy of the commons. In 1968, Garret Hardin introduces the most important models in explaining why some communities do over-exploitation of the common goods even though they know what they are doing can disrupt the long-term interests of their own so-called tragedy of the commons (Hardin, 1968). Tragedy of the commons occurs when the rational nature of man has attempted to obtain the maximum benefit for themselves into collective action that is not rational in the use of resources excessively causing harm done together over these irrational actions. The existence of this tragedy of the commons has drastically improved the environmental damage which is bad for human life.

A common indicator used in assessing the progress of a country or region development is economic growth. Ideally, when economic growth occurs, the environment remains sustainable. The fact is happening is often not balanced, while relatively high economic growth, environmental degradation is also high. This is because the economic growth achieved by relying on the exploitation of natural resources without seeking value added and not accompanied by a human resource investment. So then came the tragedy of commons. The tragedy of commons is a social trap which is usually related to economic issues concerning the conflict between the interests of individuals with public property. The tragedy of commons metaphor illustrating that free access and the infinity of natural resources will eventually cause havoc structural inevitability of resources in the form of over-exploitation which led to exhaustion of these resources. The catastrophe occurred because the profits from the exploitation only enjoyed by individuals or groups, whereas the impact of exploitation will be distributed to all those who were in need of these resources.

The tragedy of commons is caused by the thought that natural resources are owned by all the people who had been created by God, so anyone can use it. In simple logic, this principle is more or less meaningful 'If I did not take advantage of it right now, there must be other people who will use it' (Hardin, 1968:1245). This concept eventually make all residents of the plantations in England during the industrial revolution and turn it into pasture for sheep maintain, because of the high demand for wool at favorable prices. As a result, forest exploitation became uncontrollable and lead to deforestation of forests in the United Kingdom happened so fast and have a negative impact on the environment (Hardin, 1968:1250).

The tragedy of commons that seems to have encouraged a variety of illegal practices in the use of natural resources are many. These are including as illegal logging, illegal mining, and even illegal fishing. This tragedy also makes many countries that want to boost economic growth territory by facilitating permits for foreign and local investors to take advantage of natural resources. This picture seemed to make countries sell its resources freely without realizing that improving the environment is a difficult thing to do, even some natural resources cannot be repaired. That natural resources should be harnessed and used to for the greater prosperity of the people is a constitutional mandate, but the function of the environment should still be considered, including support to be able to maintain the ecological security of the region. As well as rights for future generations to continue to enjoy the comfortable surroundings and abundant resources.

\section{ROLE OF DEVELOPED COUNTRIES TOWARDS THE ESCALATION OF GLOBAL WARMING}

Industrialized countries accounted for $52 \%$ of greenhouse gas emissions that cause global warming and the climate crisis. While developing countries accounted for $48 \%$ of the rest. This was revealed by a recent report environmental research institute, nature and space Netherlands, PBL. This conclusion is derived from the calculation of greenhouse gas emissions in the period 1850 to 2010. Calculations PBL (PBL), Ecofys and the Joint Research Centre (JRC), agency of the European Union shows that the contribution of developing countries to climate change is expected to increase to $51 \%$ in 2020 , so that the contribution of developed countries fell to $49 \%$ (Vuuren, 2011).

PBL articles that have been published in the journal Climatic Change states that in the group of industrialized countries-which accounts for $52 \%$ of global greenhouse gas emissions-the United States remains the producer of greenhouse gas emissions with the largest contribution of 
18.6\%. Countries that joined the EU (by 27 countries) came second with a share of $17.1 \%$ contribution. The third position was occupied by the Russian Federation with a contribution of $7.2 \%$. While Japan, Canada, Australia and New Zealand, Ukraine, and other European countries third consecutive accounted for $2.8 \%, 1.9 \%, 1.7 \%, 1.5 \%$ and $1.1 \%$. Developing countries, which accounted for $48 \%$ of greenhouse gas emissions in the period 1850-2010 (Vuuren, 2011). Indirectly, the biggest contributor to global warming industry are the countries like the USA, the UK, Russia, Canada, Japan and China (the countries in the northern hemisphere). That is because their industry activities are very high compared to developed countries (Southern hemisphere countries).

\section{ENVIRONMENTAL DAMAGE AND ITS THREAT ON HUMAN LIFE Transboundary Air Pollution}

Air pollution is a condition in which the air quality becomes damaged and contaminated by substances that are either dangerous or harmful to the health of the human body. The presence of foreign material or substance in the air in the number and time frames will be able to cause interference in the lives of humans, animals, and plants. Air pollution gaseous between methane, sulfur oxides, hydrogen sulfide, and carbon monoxide from motor vehicles, as for intangible air pollution particles include dust, ash, and smoke. A growing number of motor vehicles and industrial tools that emit gases that pollute the environment will be more severe air pollution that occurs anyway. Air pollution can endanger the lives of living beings and the environment so that the need for efforts at limiting and reduction of air pollution.

\section{Ozone Depletion}

Global warming is an environmental issue that can cause global climate change. The global climate change occurs slowly in a long enough period, between 50-100 years. Although it occurs slowly, climate change provides an enormous impact on living creatures. Impacts that occur include: melting of polar ice, shifting seasons, and rising sea levels. The impact of an impact on the continuity of living beings. Melting of polar ice, especially around Greenland can increase the volume of water in the sea that led to the addition of sea levels worldwide. In the 20 th century there has been a sea level rise of $20-25 \mathrm{~cm}$. If half of the Greenland and Antarctica ice melt, the sea level rise occurs on average as high as 6-7 meters. The increase in the water level could leaving many land that is habitat for living creatures. Global climate change as the cause of the loss of biodiversity is still controversial for the time being. The cause of the extinction of living things can be categorized directly or indirectly. The direct causes are changes can directly cause the death of living creatures, while indirect causes are changes cause changes in other factors that cause the death of living creatures. There are four main factors that threaten the life of the species are the loss or modification of habitat. The cause of the loss or modification of habitat due to human activities, among others, changes in land to agricultural or residential pollution and pollution. Secondly, over-exploitation and overconsumption: For example, the occurrence of excessive exploitation, among others, the culture of hunting, timber sales, deforestation and animal trafficking. Third exotic species: Introductions of species in the habitat of a species can lead to competition. Last is the disease: the disease can drive the endemic or exotic species to mass death (Buckley, 2004).

\section{Water Pollution}

Industrial sector activities certainly cause externalities. Externalities are an activity linkages with other activities that are not through the market mechanism. Externalities can be positive or negative. Positive externalities of industry sector is re-utilization of waste products or waste by others e.g. solid waste generated by the textile industry in the form of sludge can be recovered into organic fertilizer, mixed fabrics Conblok manufacture, and adobe. Examples include the negative externalities is an industrial waste can cause environmental pollution. Industry produces a variety of waste, such as waste liquid, solid, gas, and others. These wastes are usually directly discharged into the environment, without going through the process of processing and handling. General industrial liquid waste directly into water bodies, such as the sea, river, or lake. Industrial wastewater is a major cause of water pollution (Mangkoesoebroto, 1993). This is certainly a threat to hu- 
mans, given that humans need fresh water to survive and fulfill their daily needs.

\section{Forest Degradation}

According to Environment Map is published in 20002012 , the remaining approximately $50 \%$ of the original tropical forest, which is 750-800 million hectares of all the tropical forests in the estimate of 1.5 billion- 1.6 billion hectares (Morgan). But this time the percentage of forests that stay was definitely smaller than this data. So it can be understood as a result of the destruction of this forest is Global Warming and Climate Change which is a very terrible disaster in this century. Based on the results of the monitoring of community projects the temperature will rise 3 degrees Celsius by the year 2030. One of the causes of $\mathrm{CO} 2$ increase is GHG which is produced by deforestation and the burning of biomass and forest conversion into non-forest land use. With this carbon stored in forest, biomass apart into the atmosphere and the earth's ability to absorb $\mathrm{CO} 2$ from the air through photosynthesis is decreasing. Additionally, global warming is often associated with a drastic rise in temperature that can lead to forest fires (Lubis, 1992). This is certainly one of the threats to human life. The loss of forests would lead to various disadvantages such as the threat of extinction of the animal population, the higher the temperature of the earth and various other losses.

\section{Global Climate Change}

Global warming impact on the more extreme changes in the weather and climate of the earth. The rainfall pattern change can be predicted without causing flooding in one place, but drought in others. Typhoons and tropical storms will be popping up with the trend of more and more powerful. We realize how hot the temperature around us lately and you can see how no predictability arrival of the rainy season or dry resulting in losses for farmers because the growing season is supposed to be done in the dry season turned out to rain. Farm fields, plantations which usually results would be destroyed by flood or drought. Residents will create more suffering for the stock of foodstuffs and other basic necessities will be much reduced and the price would be bounced up. The government also requires large amounts of money to rebuild the affected areas and tackling the disease is endemic. Africa, India, and other arid regions will suffer more severe droughts. When it comes to climate change, then human health will be in a time of uncertainty. Cases can occur at any time with the quantity and quality of the impact also cannot be ascertained. The health care system will meet a wide range of complex challenges such as rising health care costs, community experience premature aging, and various other challenges to effective prevention strategies are needed.

\section{Energy Crisis}

One of the causes of the energy crisis is that too much dependence on the world's energy supply fuel oil. Currently, most of the energy sources that are exploited in the world come from fossil fuels, such as petroleum and coal. Meanwhile, when viewed from the supply side, oil wells in the world are very old and no longer feasible to operate. Coupled with the reduction in exploration activities led to the decrease of world oil production. This production capacity reduction actually began in 1995, with the fastest decline occurred around 2002 (Intergovernmental Panel on Climate Change, 2007). Looking at the energy crisis problem, care must be more targeted so that the energy crisis is not getting worse because when the energy source cannot be obtained any longer then many projects such as industrial, educational, social and other things would be hampered. The impact of this energy crisis had begun among the people, especially the lower middle class people. Crisis of fossil fuel has an impact on the soaring price of fuel. Do not stop there. Due to rising fuel prices with a wide range of derivative products soaring food prices. $\mathrm{Fi}$ nally getting a heavier burden on society. The fate of the people even more miserable.

\section{REGIONAL COOPERATION IN ADDRESSING ENVIRONMENTAL ISSUES}

\section{ASEAN}

ASEAN is a regional cooperation for the countries in Southeast Asia. Not only to discuss the issues that are of high politics, ASEAN also discusses issues of low politics as environmental issues that has become a global threat today. ASEAN cooperation formed a basis to discuss is- 
sues of cross-border environmental pollution begins with the approval of Kuala Lumpur Accord on Environment and Development by the ASEAN Environment Ministers on 19 June 1990. The Accord calls for harmonizing the practices and the prevention of transboundary pollution. Two years later, at the 4th ASEAN Summit in Singapore, February 27 to 28, 1992, the heads of government of ASEAN states of ASEAN countries need to continue their close cooperation in the field of the environment, in particular the issue of transboundary pollution. This problem is increasingly viewed as a major environmental problem faced by ASEAN.

The statement of the head of government is caused by two things; First, the fire resumed in 1991, and secondly, the holding of the Earth Summit or Rio Summit, in Rio de Janeiro, Brazil, 1992, which adopted Agenda 21. The Earth Summit reached some agreement concerning global climate change, biodiversity, forest protection and environmental problems other life. The spirit of Agenda 21 guided the issuance of Singapore Resolution on Environment by the end AMME (ASEAN Ministerial Meeting on Asap) 5th, on 17-18 February 1992, and Bandar Seri Bengawan Resolution on Environment and Development, 26 April 1994 (Associations of Southeast Asian Nations, 2015).

Through the Hanoi Plan of Action of ASEAN leaders want the maintenance of commitment and a spirit of partnership and solidarity that has become a tradition among the ASEAN countries to achieve peace, progress and prosperity in the form of cooperation prevention and control of transboundary haze pollution. The principle of this agreement is the principle of sovereignty in sustainably managing the environment, prudence in anticipating, preventing, monitoring and remedying by involving all parties, then was reached agreement in Kuala Lumpur on Environment and Development adopted by the Ministers of the Environment ASEAN countries on June 191990 which called for efforts harmonization of transboundary haze pollution prevention and mitigation (Associations of Southeast Asian Nations, 2012). The Minister of the Environment considers the work plan specifically addresses the handling strategy transboundary pollution problems. Responding to these talks in Kuching, ASEAN held a Meet- ing on the Management of Transboundary Pollution in Kuala Lumpur in June 1995. At this meeting successfully agreed on a work plan, in order to face the problem of transboundary pollution which contained in the ASEAN Cooperation Plan on Transboundary Pollution (Associations of Southeast Asian Nations, 2015).

In the case of transboundary haze pollution, the state of the injured may sue the government because according to a number of international conventions which have also been ratified, such as the Biodiversity Convention and the Climate Change Convention and the ASEAN Agreement on the Conservation of Nature and Natural Resources in 1985, which contains a provision that the state might exploit their natural resources, but is obliged to ensure that these activities do not cause damage in the territory of another country (state responsibility). This provision has even become customary international law and binding on all civilized countries (Nations, 1985).

\section{The European Union}

The rise of issues concerning environmental damage, eventually making the EU took part in addressing environmental problems. Starting from the entry of the EU in the UN environment conference in 1972 in Stockholm (EU, 2002). After the United Nations Conference on the Environment first in Stockholm in 1972 and the public as well as scientists began to pay attention to the environmental limits to growth, the European Commission (EC) began to actively propose environmental policies. EC began to focus on environmental issues and implement relevant policies through a program with the ideas of 'sustainable development'. Based on the commitment of EC environmental policy, the enactment of the Environmental Action Programs (EAP) in 1973. The EAP was the first medium-term program and in the form of a policy strategy document that reflects the basic elements of contemporary environmental thinking and perception of environmental problems. EAP creates arguments that economic development, welfare and protection of the environment are interrelated. The three most important objectives of the program is to prevent, reduce and stop the damage to the environment, conservation of the ecological balance, as well as the use of natural resources rationally. EAP con- 
tinue to be implemented until the sixth EAP (Hey, p. 18).

In 1987, the EU made a single European act which contains a formal policy that obliges each EU member state to seek to safeguard the environment. 1992, sparked the Maastricht Treaty which make it clear that the Environmental Policy European Union should aim at protection of the environment and the Community and that environmental protection requirements must be integrated into the definition and implementation of the EU policies more and two years after that, established the European Environmental Agency (EEA), as evidence of the seriousness of the EU in environmental issues (Hey, p. 19).

\section{INTERNATIONAL ENVIRONMENTAL REGIME AND ITS ROLE IN ADDRESSING ENVIRONMENTAL ISSUES}

International environmental regime is different from other international regimes that are generally based on the interests and strengths. Environmental regime is not a regime that is based on the interests of the regime because it is a non-profit and is based consciousness or awareness (Stokke, 2006). Environmental regime relies heavily on the issue of certain areas so as to demand a common awareness in achieving the objectives of the regime's effectiveness because the environment is not to share certain advantages but for the common interest. International environmental regime is not based on force because its effectiveness is not dependent on the actor hegemon but the collective decision or a joint decision (Stokke, 2006). The regime is more embracing environment spontaneous order because environmental protection is a form of collective security action.

\section{The United Nations Framework Convention on Climate Change}

Launched in 1992 and enacted in 1994, establishes a primary purpose of stabilizing the concentration of greenhouse gases in the atmosphere at a level that will prevent dangerous human intervention in the climate system (The World Bank, 2010). UNFCCC established on 1992 in the Rio Summit in Rio de Janeiro, Brazil which has the objective to negotiate an agreement that is widespread in reducing and limiting the impact of global warming. UNFCCC draw up a framework for action towards controlling and limiting emissions.

UNFCCC was finally accepted universally as a political commitment internationally on climate change and then opened for signature at the Earth Summit on Environment and Development (United Nations Conference on Environmental and Development) in Rio de Janeiro, Brazil in June 1994 and started finalized on March 21, 1994 after ratification by 50 countries. There are 189 countries that ratified the convention and the countries that ratified the so-called parties (state parties) (United Nations Sustainable Development, 1992).

\section{Kyoto Protocol}

Weak commitment of the Parties to the Convention on Climate Change, Conference of the Parties (COP) III, held in Kyoto in December 1997 which resulted in a consensus that such a basic decision for industrialized countries to reduce greenhouse gas emissions combined fewest per cent from 1990 levels before the period 2008-2012. Legally binding commitments will restore the tendency of increase in emissions which historically started in these countries 150 years ago. Kyoto Protocol so that the protocol hereinafter called, arranged to set a target date for developed countries to reduce emissions. Meanwhile, developing countries have no obligation or commitment to lower emissions (Murdiyarso, 2007). Under the Kyoto Protocol, developed countries or industries must comply under the law binding on controlling emissions of six greenhouse gases, namely: Carbondioxide, Methane, Nitrousoxide, Hydrofluorocarbons, perfluorocarbons, and Sulfurhexafluoride (Jones, 2015).

The Kyoto Protocol aims to keep greenhouse gas concentrations in the atmosphere that are at a level that does not harm the earth's climate system. To achieve that goal, the implementation of the Protocol set emission reduction by industrialized countries by 5\% below 1990 levels in the period 2008-2012 are created in a principle of cooperation that can be seen on existing mechanisms such as the Kyoto Protocol (WWF). Joint Implementation is a mechanism that allows developed countries to establish joint projects can generate credits or a decrease in absorption of GHG emissions. Joint Implementation is a mechanism to transfer emission reduction units derived from an 
activity or program that is carried out in developed countries to more developed countries. This means that any activity or program that is made by a country in other countries will provide emission reduction units for countries that conduct such programs (U.S. Environment Protection Agency).

But along the way, Kyoto Protocol reaps the failure through which countries with advanced industry and the economy felt aggrieved by this Protocol. This is apparent from the retreat of the United States and Canada from the Kyoto Protocol (Mistrick, 2013). From here, one can see that the failure of this protocol may be the failure to bind states largest emitters to join and fight alongside environmental damage in the regime. Moreover, the absence of binding commitments sanctions also gives the opportunity for the member countries such as Canada to retreat (The Guardian, 2011). The successor regime might be able to bring more significant results if there is real action from donor countries with largest greenhouse gas emissions or it may also repeat the mistakes of the previous regime. Nothing is certain in this regard that sure was the fact that environmental issues requires the involvement and greater attention from international actors.

\section{Vienna Convention}

To secure the ozone layer it is necessary to establish an international regime to regulate the amount of substance depleting the ozone layer that is produced by the big countries. Before setting phase of substances depleting the ozone layer, the countries concerned with the problem of ozone agreed to make regulations on the protection of the ozone layer, known as the Vienna Convention (Vienna Convention for the Protection of the Ozone Layer) (Ministry of Environment, 2011). The Vienna Convention is a form of international concern about the problem of ozone layer depletion that occurred in 1985. To address the issue of the environment, especially the ozone problem, then on March 22, 1985 established the Vienna Convention (Vienna Convention for the Protection of the Ozone Layer) in Vienna, Austria. The purpose of the Vienna Convention is that the countries agreed to protect humans and the environment from the dangers of ozone depletion (deletion ozone layer) through research, observation, and even the exchange of information. In 1985, countries that have ratified the Vienna Convention amounted to 184 countries on 13 March 2007, members of the Vienna Convention has been ratified is 191 countries (UNEP, 2015).

\section{Montreal Protocol}

The history of the birth of the Montreal Protocol set out from two research chemists from the University of California, Rowland and Molina, in 1974 which gave a hypothesis as well as an 'early warning' about the relationship destruction of the ozone layer due to chlorine gas contained in the compound CFC (Chlorofluorocarbons). Chlorine gas that can last up to hundreds of year is indicated as the cause of the depletion of the ozone layer. Then in 1985, Farman conducted a study and found the hole in ozone (ozone hole) on the Antarctic continent. This condition eventually becomes a very interesting conversation among students of the environment. Ozone is a colorless gas composed of three elements of oxygen $(\mathrm{O})$. Chemically, ozone is very active and reacts with a number of other substances. Ozone can have a positive impact when it is in normal conditions. One of the properties is excellent ozone are able to absorb ultraviolet-B (UV-B) that is very damaging to human health and the environment, then when ozone under conditions that occur is perforated complex issues to people and the environment (UNEP, 2015).

When ozone in the standard amount of the ozone layer will function optimally. Ozone will protect the world from a variety of well damage that occurs in the human body and the environment. The destruction of nature that swept the world today as well as the emergence of many diseases that afflict the world community representation on the lack of oversight and regulation of the ozone layer. The ozone layer that functions as a filter against ultraviolet light has been damaged by the emergence of free radicals substances such as CFCs (chlorofluorocarbons). The Montreal Protocol (the Montreal Protocol on Substances that Deplete the Ozone Layer) declared by States Parties at the date of the Montreal Protocol in 1987, the Parties to the Montreal Protocol ratified very little, which ranges from 31 States Parties (UNEP, 2015). However, with the passage of time and the insistence of the international community and groups of observers of environmental issues par- 
ticularly the issue of the depletion of the ozone layer over the Antartic continent, the number of countries that have ratified the Montreal Protocol until the 13th of March 2007 reached the number range which is amazing that 191 countries and only five countries that have not ratified the Montreal Protocol. These five countries are Iraq, Andorra, Timor Leste, Holy Sea, San Marino.

\section{Copenhagen Protocol}

Until 2009, UNFCCC has conducted the Conference of the Parties (COP) for fifteen times. COP-15 held in Copenhagen, Denmark. Before COP-15 took place, there were several previous conferences held by the UNFCCC. One of the most important is the COP-3 in 1997 which was held in Kyoto, Japan. The conference resulted in the Kyoto Protocol which is seen as an important first step towards global emission reduction regime that will stabilize GHG emissions and provide the important architecture in any international agreement on climate change in the future. UN Climate Change Conference fifteenth (COP-15) held by the Danish government on December 7 to 19, 2009 in Copenhagen (UNFCCC, n.d.). At the conference considered important to the global climate, the Danish government and UNFCCC member states. To that end, both the Danish government and UNFCCC member countries working hard to make the Copenhagen conference a success by generating a Copenhagen Protocol to prevent global warming and climate change. This is done because in 2012 the Kyoto Protocol will expire. An agreement which appears in Copenhagen protocol is copenhagen accord. In the Copenhagen Accord on January 2010 stated that each country should establish GHG emission reduction target by 2020 but will not be legally binding as the Kyoto Protocol in 1997 (YD 2009). In the Copenhagen Accord, UNFCCC member countries make commitments on the reduction of climate change and must be agreed by all member states (UNFCCC n.d. 18).

The EU has committed to implement binding legislation, even without a good deal in Copenhagen. The European Union carbon allowances revise the system of so-called Emissions Trading Scheme (ETS) is designed for the postKyoto period. This new phase aims at further reducing greenhouse gas emissions in Europe by binding to and demonstrate the commitment of the European Union have been done before the Copenhagen meeting. Then the results of this meeting make European countries and others to reduce their emissions by a certain percentage within a period of time long enough. But there is a demo during the first week of the conference. A mass protests took place in Copenhagen on 12 December (BBC, 2009). They have assumed the conference is part of colonialism because not too concerned with developing countries. There is a document that is dispersed, known as 'The Danish Text' has started an argument between developed and developing countries. The document is titled 'The Copenhagen Agreement' and proposes measures to keep average global temperature rises to two degrees Celsius above pre-industrial levels.In a way, Copenhagen Accord failed. It is due to the pressures from businesses that received by the advanced industrial countries such as China and the United States. That deal in Copenhagen Accord will weaken their power in the business and industry sectors. The non-binding agreement to make the commitment of countries are very weak.

\section{IMPORTANCE OF POLITICAL REGIME TO ADDRESS GLOBAL ENVIRONMENTAL ISSUES}

Request of a regime is closely related to its effectiveness, the more effective a regime dealing with a specific issue, the higher the demand for actors to such regimes. Economists define effectiveness as a comparison of the benefits of the results of what is given and the costs associated with the achievement obtained, such understanding is then used as an initial evaluation of public policies (Stokke, Determining the Effectiveness of International Regimes, 2006, p. 4). Their demand for international environmental regime is motivated by three things: first, the domestic environmental management is no longer effective to solve the problem, requiring effective cooperation among fellow nations. Second, the increasing scale of regional and local environmental problems, such as urban degradation, deforestation, desertification, sanitation, denudation, or water scarcity. Third, the complex relationship between the world economy with an increasingly globalized environmental problems. Thus the author concludes that the environmental regime is a form of coop- 
eration among the actors who put environmental issues as a specific issue area. The international environmental regime is formed on the basis of the insistence of the issues that continue to increase so that the necessary role of the regime that according to Martin List and Volher Ritterberger regime can manage conflict and issues of mutual interest. This regime includes legal regulations, norms, rules and decision-making procedures either explicitly or implicitly within the scope of hope for all actors in a specific area of international relations (Hurrel \& Benedict in Dewi Utariah, The International Politics of The Environment, n.d).

The importance of the completion of this environment due to the high uncertainty in which the definition and limitation issues, costs of alternative policy responses, and the identity of the actor with interests far from self-evident. There are three consequences of the environmental regime, among others, the first research collaboration occurs especially since the Stockholm Conference in 1972, which collects information and supporting research on the nature and content of environmental problems. Second, a long negotiation to decide which aspects should be included in the settlement of the issue by considering the complexity of the science area and the link between environmental issues with economic processes. Third, alignment and flexibility in cooperation and joint management in view of the seriousness of environmental issues (particularly climate change, ozone depletion, loss of biological diversity, forest protection). Environmental regime can be instrumental in helping to overcome the problem of insurance and provision of incentives for the losses. State prefers to work though contrary to the interests of shortterm, they will be more concerned with their reputation as a trustworthy partner and their long-term interests in the international system. Regime legal environment can stabilize expectations and instituted a statement that the state is involved in its partnership long term and in the negotiations on a growing issue, they are not only concerned with the deals one problem at a particular time (Hurrel \& Benedict in Dewi Utariah, n.d.).

In addition, the importance of international environmental regimes in solving environmental problems is the fact that environmental problems cannot be completed if there are only a few parties that moved. Environmental problems are complex issues, which in the settlement required the awareness of all actors in the world to begin to maintain and improve the environment. The presence of the international regime is expected to become an international forum for all actors to join and discuss the appropriate measures to solve the problems of environmental crisis. This is why international environmental regimes considered important in discussing issues related to the environmental crisis.

\section{FAILURE OF INTERNATIONAL ENVIRONMENTAL REGIME}

International regime until now is still believed to be a way out for global environmental problems. But in fact the international environmental regime is one of the international regimes that are difficult to identify because the regime is non-profit and depends on issues of particular areas. So it is very difficult to solve the problem in global scope with a regional approach because nature cannot be simply changed without human intervention. Difference principal between advanced and developing countries are a source of potential confrontation for the global environment between North and South, which turns it into an international political issue that is fundamental. Three important aspects of the problem: (1) a striking asymmetry between North and South in the availability of resources are global, such as ozone depletion and global climate change; (2) the global environment must accommodate the needs of future development in the South; and (3) failure to support the economy more sustainable form in the South, which is less influential to the first acts of environmental measures undertaken Holland (Hurrel \& Kingbury, 2006). Not only that, some of the factors that hinder the effectiveness of the regime of the global environment, including a high level of scientific uncertainty and economics, it is difficult to implement a negotiation, because the cost of environmental degradation is sudden and cannot go down at any time, it is still unclear definition of sustainable development, and conflict on various issues relating to sovereignty (Hurrel \& Kingbury, 2006). With the swift currents of globalization, mobility, as well as human needs-even higher. To meet these needs, exploitative acts of nature-was inevitable. 
International environmental regime is a regime that is different from other international regimes. These are generally based on the interests and strengths. Environmental regime is not a regime that is based on the interests of the regime because it is a non-profit and is based consciousness or awareness. Because environmental regime based on the aspect of consciousness then there are various difficulties and obstacles in the implementation of the framework and rules agreed in various aspects. Basically, people realize the importance of the environment, but on the other hand for the welfare of people in need of development. So there is a dilemma in its implementation. Moreover, the state will be more concerned to meet the needs of the people that the state is not said to fail in carrying out its functions. The absence of a binding legal brings difficulties for a regime to measure the compliance of each member.

International environmental regimes in the process of implementation is often faced with issues such as conflict of interest and the difficulty of reaching agreement by consensus. This is evidenced by the lack of effective multiple agreements such as the Kyoto Protocol because of the unwillingness of some countries, especially industrialized countries to engage in environmental regime is due to the conflict of interest between the carbon emission reduction agreement and also the economic development of the industrial sector. The author argues that the international environmental regime is very influential in the social-political life in the present and the future but the need of their awareness of all the actors in the success of the international environmental regime.

The failure of a state and international environmental regime in dealing with the environmental crisis can be analyzed through the lens of game theory in particular prisoner's dilemma. Prisoner's dilemma is a paradox in the analysis of decisions in which the two actors who act in their own best interests pursuing an action that does not produce ideal results. Typical dilemma of prisoners has been arranged so that both parties choose to protect themselves at the expense of other participants. As a result of adhering to purely logical thought process to help yourself, both actors find themselves in a worse situation than if they had cooperated with each other in the decision- making process. State, an actor who pretty much blamed for environmental problems, the situation 'prisoner's dilemma' often times be a barrier for them to cooperate in order to maintain the integrity of the environment together. Situations where their own interests, in this case the state, becomes a barrier for the necessary collaboration for mutual benefit, namely the preservation of the environment. Both developing countries and industrialized countries are often confronted with the situation. So, the assumptions regarding the maintenance of the environment sometimes clash with the interests held by each country to fulfill the development needs of the country cannot be denied.

\section{CONCLUSION}

Interesting indeed talking about the topic of environmental crisis, especially global warming. This is because the effects of global warming can be felt directly in the everyday life. Of the many discussions in the previous section, it can be concluded that the process of globalization emerged as a result of current developments urgings of contemporary human history where conventional boundaries of traditional good-politically, geographically, regionally has shifted. Globalization is often associated with the phenomenon of the industrial revolution. Advances in technology and the shifting global issues make nations simultaneously undertake industrial revolution in order to strengthen the economic foundation of the country. The entry of the world into an era of globalization has also become an entry point for neoliberal to instill their principles. Heightened industry competition made countries increasingly prioritize the development of their industry. The era of globalization is the era in which the progress of the industry is used as a benchmark to determine a country has developed or been managed. The principle of construction according to neoliberalism, economic actors are required to compete with one another to control the market. This then encourages countries to always attach great importance to the development and ignore other things.

The development of industry and globalization followed by the emergence of multi-national corporations (MNCs) operating in different countries to expand their markets. The economic principle that emphasizes the advantages brings harm to countries that cooperate with the MNC. 
That is because the MNC has a principle to maximize profits with minimal capital. So, the exploitation of natural resources is very high. The emergence of the term tragedy of commons also makes overexploitation higher. Therefore, there is continuity between globalization and development. That globalization becomes a starting point of commencement of construction-development undertaken by various countries to promote the country. But along the way, globalization and development turned out to cause a few things then the cause of environmental damage and exacerbate global warming.

Global warming is a global issue that requires cooperation in the solution. Awareness of the need for cooperation make the people of the world are trying to create a regime to solve global environmental problems. This then encourages cooperation among countries of the world both on a regional level such as ASEAN and the EU to begin concerned with issues other than security and economics that is environmental problems. The international community also realized that addressing the environmental concerns must at the international level as well. This then encourages the emergence of international environmental regimes as a forum for the entire international community in dealing with international problems. Beginning with the implementation of the Conference of Stockholm in 1972 which raised the issue of climate change led by the World Meteorological Organization (WMO) and the Earth Summit Rio de Janeiro in 1992 which discussed energy strategies linked to global warming, including the reduction of greenhouse gas implications for damaging the environment also the United Nations Framework Convention on Climate Change (UNFCCC) that discussed climate change as a serious threat to human life and environmental threats. It is not stop there, appears the Kyoto Protocol, the Vienna Convention, the Montreal Protocol to the Copenhagen Protocol which became a forum for the international community in tackling the problem of environmental degradation. However, not all regimes environment are effective, there are some inhibiting the effectiveness of the regime, among other things because of the high level of scientific uncertainty and the economy, the difficulty of carrying out negotiations, the cost of environmental degradation that suddenly cannot go down at any time, it is still unclear definition of development sustainable, and conflict on various issues relating to sovereignty. Besides problems of sharing the costs of environmental management and the seriousness of the conflict, the principal difference between advanced and developing countries is also contributing to the failure of the international regime. So, we need an idea or a new idea in the case of environmental damage so that a regime can work perfectly.

Worsening of global warming that happens is to encourage various groups to start thinking about the right way to tackle global warming. Indeed, it is undeniable that environmental regime have not been able to bring significant changes in response to environmental problems. There are various alternative roads can actually reached the international regimes. Two of them are creating a more binding agreement; and create mechanisms to be an incentive in the form of economic benefits to make the country well behaved. Basically, these two mechanisms move on the principle of reward and punishment: when obedient it will be rewarded, and when not obedient then it will have bad consequences. Solutions that can be taken is to raise a joint commitment of all stakeholders tech businesses are not environmentally friendly (involving the government and corporate) to shift the orientation of the business (product development and sales) to the orientation of environmentally friendly technologies. When such a commitment has been made possible, environmentally friendly technology which had been acting as a competitor can become a source of new revenue. By doing so, the business environment-friendly energy will be an incentive for the parties concerned. If this happens, the willingness to develop renewable technologies both in business and in technology will be greater.

The new challenge is how to reconcile the interests of countries that have rich from oil or other nonrenewable resources, such as oil-producing countries in the Middle East or coal-producing countries. Efforts to 'adjustment' interests can be done by providing technology transfer and more segmented marketing for the products of non-renewable energy, so that the parties of non-renewable energy producers still have time to adjust to the 'order' of new more environmentally friendly. Of the amount mentioned, the expected reduction of environmental issues can be a 
point of light and improved in the future for the benefit of the next-generation successor.

\section{END NOTE}

Although globalization is acknowledged to be a consequence of modernity, it also can not only be cultural flows in one direction. During the 80s and 90s, academic debate among scholars open space for formulation in view of globalization as an increase in contact between cultures, not as an imposition of the dominant culture on other cultures.

2 The Cold War, the international system polarized into two blocks: the West Block (liberal) led by the United States and the Eastern Bloc (communist) led by the Soviet Union. At that time, there was no homogeneous system because the world is divided into countries with liberal and communist. Globalization also not been growing rapidly despite the initial stages of its development has been started around the 16th century when the empire's military and political power expansively at the time. Read more depth Pasaribu Rowland B. F., (2011). Political Economy of Globalization. P. 516

3 This agreement is known as the Bretton Woods system. This system has a useful life of 1944 to 1970s. The Bretton Woods conference was attended by representatives of 44 countries and was held in 1944 at Bretton Woods, New Hampshire, United States. Initially had 30 members in 1945 and now more than 180 member countries. Agreement includes an agreement to establish three international monetary institutions, namely the International Monetary Fund (IMF), International Bank for Recontruction and Development, commonly referred to IBRD and often called the World Bank, and the International Trade Organization, commonly called ITO, has developed into World Trade organization World Trade Organization (WTO). Read more Budi Winarno, Pertarungan Negara Versus Pasar, (Yogyakarta: MedPress, 2009), p. 116-117. The Bretton Woods system had also been shelled in the Perspective of Islam, such as writing Ayif Fathurrahman, (2011), the Bretton Woods system in the Perspective of Islamic Maqasid.

\section{REFERENCES}

Books and Journal

Becker, Jasper. 2007. Dragon Rising. National Geographic Society: Washington DC.

Brown, R. Lester. 1992. Challenges Environmental Problems (How People Based Community Development Sustainability Healthy Environment). Translated by S. Maimoen, Jakarta: Yayasan Obor.

Bruff, Ian. 2005. 'Making Sense of the Globalization Debate when Engaging in Political Economy Analysis.' British Journal of Politics and International Relations, Vol. 7.

EU. 2002. 'A European strategy for Sustainable Development,' Luxemburg: EU Commission Office: Official Publications of The European Communities. Luxemburg.

Friedman, Jonathan. 1994. Cultural Identity and Global Process. London: Sage.

Friedman, Milton. 2002. Capitalism and freedom. Chicago: The
University of Chicago Press.

Giddens, Anthony. 1990. The Consequences of Modernity, Cambridge: Polity Press.

Hey, Christian. 'EU Environmental Policies: A short History of the Policy Strategies,' in EU Environmental Policy Handbook.

Julian, Timothy S. 2008. Contemporary Global Politics: Theory, Actors, Issues and Analysis by Budi Winarno.

Kahle, R. Lynn \& Atay, Gurel Eda. Eds 2014. Communicating Sustainability for the Green Economy. New York: M.E. Sharpe.

Katy, Gardner. David, Lewis. 2005. Anthropology of Development and Challenges of Post-Modern. Translation Joseph M. Florisan. Ledalero: Maumere.

Ladislaw, Sarah. O. 2010. U.S. Domestic Politics of Climate Change. Washington D.C: Center for Strategic \& International Studies.

Lubis, Mochtar. 1992. Preserving Tropical Forest: Issues, Benefits and Policies. Jakarta: Yayasan Obor Indonesia.

Mangkoesoebroto, Guritno. 1993. Public Economy. Yogyakarta: Edisi-III, BPFE.

Martell, Luke. 2009. 'Globalization and Economic Determinism,' Paper given at Global Studies Association Conference, Challenging Globalization. London: Royal Holloway.

Mason, J. Robert. 1999. 'Wither Japan's Environmental Movement?' An Assesmenty of Problem And Prospect At National Level. Vol. 72, No. 2.

Murdiyarso, Daniel. 2007. Kyoto Protocol: Implications for Developing Countries. Jakarta: Buku Kompas.

Pasaribu, F. B. Rowland. 2011. Political Economy of Globalization. Yogyakarta: University of Muhammdiyah Yogyakarta.

Pontoh, Husain Coen. 2003. End of Globalization: From Debate Theory of Mass Movement Toward. Jakarta: C-Books.

Pieterse, Jan Nederveen and Parekh, Bikhu. 1995. The Decolonization of Imagination: Culture, Knowledge and Power, New York: Oxford University Press.

Robins, Nick, Robert Clover \& Charanjit Singh. 2009. 'A Climate for Recovery: The Colour of Stimulus Goes Green,' HSBC Global Research.

Schreurs, A. Miranda dan H. Imura (eds.). 2005. Environmental Policy in Japan. Northamton: Edward Elgar Publishing Limited.

The World Bank. 'World Development Report 2010: Development and Climate Change in 2010'. (Washington: The International Bank for Reconstruction and Development, 2010).

Trewartha dan Horn. 1995. Climate Introduction. Yogyakarta: Gadjah Mada University Press.

United Nations Sustainable Development. United Nations Conference on Environment \& Development Rio de Janerio, Brazil, 3 to 14 June 1992 Agenda 21.

Watson, A. Hilbourne. 2002. Globalization as Capitalism in the Age of Electronics Issue of Popular Power, Culture, Revolution, and Globalization from Below'. Latin American Perspective.

Winarno, Budi. 2009. Pertarungan Negara Versus Pasar, Yogyakarta: MedPress.

World Meteorological Organization. 2011. 'Twenty Questions and Answers about the Ozone Layer'. Scientific Assessment of Ozone Depletion: 2010

Online Articles

Associations of Southeast Asian Nations. 2015. ASEAN Coopera- 
tion on Environment: Resolution on Environment and Development. Environment.asean.org (Online), http:// environment.asean.org/resolution-on-environment-anddevelopment-2/

Associations of Southeast Asian Nations. 2015. ASEAN Cooperation on Environment: ASEAN Cooperation on Transboundary Haze Pollution. Environment.asea.org (online), http:// environment.asean.org/asean-cooperation-on-transboundaryhaze-pollution/

Associations of Southeast Asian Nations. 1985. ASEAN Cooperation on Environment: Agreement on the Conservation of Nature and Natural Resources. Environment.asean.org (online), http://environment.asean.org/agreement-on-the-conservationof-nature-and-natural-resources/

Associations of Southeast Asian Nations. 2012. Hanoi Plan of Action. Asean.org (online), http://asean.org/

?static_post $=$ hanoi-plan-of-action

BBC. 2009. 'Climate activists condemn Copenhagen police tactics'. BBC News (online), http://news.bbc.co.uk/2/hi/europe/ 8410414.stm

Baker, G. 2016. China and the United States of America Agrees to Reduce CO2 Emissions. Dw.com (online), http://www.dw.com/ id/cina-dan-as-sepakat-kurangi-emisi-co2/a-18058029

Buckley, L. B; Roughgarden. 2004. 'Biodiversity Conservation: Effects of Changes in Climate and Land Use'. Nature.com (online), http://www.nature.com/nature/journal/v430/n6995/ abs/nature02717.html

Detlef P. van Vuuren, James A. Edmonds, Mikiko Kainuma, Keywan Riahi, John Weyant. 2011. Climatic Change: An Interdisciplinary, International Journal Devoted to the Description, Causes and Implications of Climatic Change. Springer.com (online), http://link.springer.com/journal/10584

'Guide to The Kyoto Protocol', accessed from http:// yosemite.epa.gov/oar/globalwarming.nsf/uniqueKeyLookup/ SHSU5BUQN2/\$File/Kyoto.pdf

Hardin, Garrett. 1968. The Tragedy of Commons. (PDF Online), http://www.environnement.ens.fr/IMG/pdf/hardin_1968.pdf

Harte, John et. al. 2006. 'Shifts in plant dominance control carboncycle responses to experimental warming and widespread drought'. Environmental Research Letters 1. Iopscience.iop.org (online), http://iopscience.iop.org/article/10.1088/1748-9326/1/ 1/014001/fulltext/

Hurrel, Andrew \& Kingbury, Benedict. (2006). 'The International Politics of The Environment: Introduction'. In Dewi Utariah, The International Politics of The Environment. (PDF), http:// pustaka.unpad.ac.id/wp-content/uploads/2009/05/ the_international_politics_of_the_environment.pdf International Energy Agency. 2011 . Solar Energy Perspectives: Executive Summary. OECDMEA. (PDF Online), http:// www.iea.org/Textbase/npsum/solar2011SUM.pdf

IPCC (Intergovernmental Panel on Climate Change). 2007. Climate Change 2007: The Physical Science Basis. Summary for Policy Makers, Contribution of Working Group I to the Fourth Assessment Report of the Intergovernmental Panel on Climate Change. (online), http://www.ipcc.ch/

Jones, Craig. 'The Kyoto Protocol: Climate Change Success or
Global Warming Failure?' Circular Ecology (online). 3 February 2015. http://www.circularecology.com/news/the-kyotoprotocol-climate-change-success-or-global-warmingfailure\#.Vt2kJJx97IW

Krukowsk, E. 2010. UN Approves Russian Joint implementation CO2 Reduction Project E.ON. Bloomberg.com (online), http:// www. bloomberg.com/news/2010-10-18/un-approves-russianjoint-implementation-Co2-reduction-project-by-e-on.html0020 dalam Yale Center for Environmental Law and Policy, Climate Change Solutions: Front-Line Perspectives from Around the Globe: Climate Policy \& Emis-sions Data Sheet: Russia, (online).

Levy, Brandon. 2012. The Role of Globalization in Economic Development. (PDF Online), https://papers.ssrn.com/sol3/ papers.cfm?abstract_id $=2233648$

Ministry of Environment. 2011. 9th Conference of The Parties (COP) to Vienna Convention For The Protection of Ozone Layer. Men/h (online), http://www.menlh.go.id/siaran-pers-9th-conferenceof-the-parties-cop-to-vienna-convention-for-the-protection-ofozone-layer/

Mistrick, Janine. 'Kyoto Protocol: Good Intentions, Failed Legislation?' Pensive Thoughts and Frivolous Musings (online). 21 February 2013. https://sites.psu.edu/mistrickblog/2013/02/21/ kyoto-protocol-good-intentions-failed-legislation/

Morgan, James. Forest Destruction Map Created. Bbc.com (online), http://www.bbc.com/indonesia/majalah/2013/11/ 131115_iptek_petahutan

Muir, Patricia. 2008. 'Stratospheric Ozone Depletion'. Oregon State University (online), http://people.oregonstate.edu/ muirp/ stratozo.htm

'Overview of Climate Change in the International Negotiating Framework', accessed from http://www.wwf.or.id/admin/fileupload/files/FCT1189527007.pdf

Palley. I. Thomas. 2004. From Keynesianism to Neoliberalism: Shifting Paradigms in Economics. Foreign Policy in Focus (online), http://fpif.org/ from_keynesianism_to_neoliberalism_shifting_paradigms_in_economics/

Shah, Anub. 2002. Corporate Interest and Actions Can Harm the Environment. Glabalissues.com (online), http:// www.globalissues.org/article/55/corporations-and-theenvironment\#Corporateinterestsandactionscanharmtheenvironment

Stokke, Olav Schram. 2006. Determining the Effectiveness of International Regimes. (PDF Online), http://www.svt.ntnu.no/ iss/fagkonferanse2007/intern/papers/ olav.s.stokke@fni.noStokkeDetermRegimeEffectiveness.pdf

The Guardian, Canada pulls out of Kyoto protocol (online). 12 December 2011. http://www.theguardian.com/environment/ 2011/dec/13/canada-pulls-out-kyoto-protocol

UNEP. 2015. The Montreal Protocol on Substances That Deplete The Ozone Layer. Ozone Secretariat (online), http:// ozone.unep.org/en/treaties-and-decisions/montreal-protocolsubstances-deplete-ozone-layer

UNEP. 2015. The Vienna Convention for The Protection of The Ozone Layer. Ozone Secretariat (Online), http:// ozone.unep.org/en/treaties-and-decisions/vienna-conventionprotection-ozone-layer

United Nations. Framework Convention on Climate Change. 
UNFCCC (PDF Online), http://unfccc.int/resource/docs/2009/

cop15/eng/l07.pdf

Vargo, Frank. 2011. 'U.S. Manufacturing Remains World's Largest'. Shopfloor.org (online), http://www.shopfloor.org/2011/03/u-smanufacturing-remains-worlds-largest/18756/

whitehouse.gov. 2009. White House (online), http:// www.whitehouse.gov/the-press-office/Joint-press-statementpresident- obama-and-president-hu-china whitehouse.gov. 2009. White House (Online), http:// www.whitehouse.gov/the-press-office/joint-statementbetween-prime-minister-dr-singh-and-president-obama whitehouse.gov. 2009. White House (online), http:// wvvw.whitehouse.gov/the-press-office/Fact-Sheet-andParticpants-at-Todays-Rose-Garden-Event

whitehouse.gov. 2009. White House (online), http:// vww.whitehouse.gov/the office/Statement-On-BilateralMeeting-With-President-Hu-Of-China

whitehouse.gov. 2009. White House (online), http:// www.whitehouse.gov/administration/eop/ceq/sustainability whitehouse.gov. 2009. White House (Online), http:// www.whitehouse.gov/the-press-office/remarks-presidentduring-press- availability-copenhagen

World Health Organization. Climate Change and Human Health. World Health Organization (online), http://www.who.int/ globalchange/en/ 